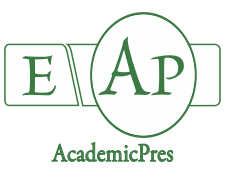

Rakascan N et al. (2021)

Notulae Botanicae Horti Agrobotanici Cluj-Napoca

Volume 49, Issue 1, Article number 12270

DOI:10.15835/nbha49112270

Research Article



\title{
Effect of digestate from anaerobic digestion on Sorghum bicolor L. production and circular economy
}

\section{Nikola RAKASCAN ${ }^{1}$, Gordana DRAZIC ${ }^{1}$, Vera POPOVIC ${ }^{2 *}$, Jelena MILOVANOVIC ${ }^{1}$, Ljubisa ZIVANOVIC ${ }^{3}$, Milena ACIMIC REMIKOVIC $^{4}$, Tijana MILANOVIC 5 , Jela IKANOVIC 3}

\author{
ISingidunum University, Danijelova 32,Belgrade, Serbia;n.rakascan@biogasenergy.rs; gdrazic@singidunum.ac.rs; \\ jmilovanovic@singidunum.ac.rs \\ ${ }^{2}$ Institute of Field and Vegetable Crops, Maksim Gorky 30, Novi Sad, Serbia; \\ drvvpopovic@gmail.com ("corresponding author) \\ ${ }^{3}$ University of Belgrade, Faculty of Agriculture, Nemanjina 6, Belgrade, Serbia; ljuba@agrif.bg.ac.rs; jela@agrif.bg.ac.rs \\ ${ }^{4}$ University of Montenegro, Faculty of Law,July 13, Podgorica, Montenegro; milena_acimic@hotmail.com \\ ${ }^{5}$ University of Belgrade Faculty of Organizational Sciences, Jove Ilica 154, Belgrade, Serbia; tijana.milanovic@bpa.edu.rs
}

\begin{abstract}
The aim of the research was determination the efficiency of application $50 \mathrm{t} \mathrm{ha}^{-1}$ digestate from the process of anaerobic digestion on the productivity of sorghum (Sorghum bicolor L.) on moderately degraded (calcic gleysol) and fertile (chernozem) agricultural land, in southern Banat, Republic of Serbia. In the field experiment during three years digestate amendment led to an increase in the number of leaves by $28.56 \%$ and plant height by $5.34 \%$, which led to an increase in yield by $3.40 \%$. The maximum yield was 2018 (41.74 DM t $\mathrm{ha}^{-1}$ ) on chernozem. The yield of sorghum was lower on calcic gleysol compared to chernozem by $5.43 \%$ and was in positive, medium and very significant dependence on precipitation $(0.61)$ and in positive significant correlation with digestate (0.53) and plant height (0.59). Biogas yield reach $157.05 \mathrm{Nm}^{3} \mathrm{t}^{-1}\left(9582 \mathrm{Nm}^{3} \mathrm{ha}^{-1}\right)$ on chernozem with digestate. Digestate had a statistically significant positive effect on all tested characteristics of sorghum as well as biogas yield during all three experimental years. The use of digestate as a by-product in the process of producing biogas based on silage of sorghum, allows the substitution of mineral fertilizers and remediation of damaged soil, which contributes to sustainability from the bio-economic and environmental aspects.
\end{abstract}

Keywords: agri-energy crop; biogas; bio-fertilization; circular economy; marginal soil

\section{Introduction}

The production and use of biogas as a renewable energy source, contribute to several goals of sustainable development (SDG): zero hunger, good health and well-being, gender equality, clean water and sanitation, affordable and clean energy, industry, innovation and infrastructure, sustainable cities and communities, climate action and life on land. In order to achieve sustainability, it is necessary, in addition to the energy purposes, to fulfil the environmental characteristics of this process, primarily disposing of biological waste,

Received: 13 Feb 2021. Received in revised form: 11 Mar 2021. Accepted: 16 Mar 2021. Published online: 23 Mar 2021.

From Volume 49, Issue 1, 2021, Notulae Botanicae Horti Agrobotanici Cluj-Napoca journal will use article numbers in place of the traditional method of continuous pagination through the volume. The journal will continue to appear quarterly, as before, with four annual numbers. 
reducing of the net production of gases with the greenhouse effect (primarily $\mathrm{CO}_{2}$ and $\mathrm{CH}_{4}$ ), maintenance of the fertility of agricultural land and to use marginal land with simultaneously remediation (Galeye et al., 2019). Biomass used either in thermo-chemical or biochemical processes is a "biodegradable part of products, waste and residues of biological origin from agriculture (including material of plant and animal origin), forestry and related industry, including fisheries and aquaculture and also a biodegradable part of industrial and municipal waste" (EP 2009: Directive 2009/28 / EC). Developing countries show expressed interest for biomass utilization as renewable energy source because their economies are mainly based on agriculture (Kirubakuna et al., 2009).

Anaerobic digestion $(\mathrm{AD})$ is a widespread energy transformation technology that simultaneously minimizes negative environmental impacts caused by inadequate residue management from agricultural production, primarily animal husbandry. During the AD process are obtained biogas and digestate. Biogas can be used directly or for the production of electricity. Digestate (ADD), usually contains significant amounts of macro and micronutrients, and it is used as bio-fertilizer or amendment (Mortola et al., 2019) in order to avoid synthetically produced fertilizers by replacement a closed nutrient cycle between crops and soil (Nabel et al., 2017). Crops are cultivated dedicatedly for $\mathrm{AD}$ for stabilizing or improving other raw materials (such as poor sludge, food waste with unstable composition). The most commonly used are corn, grass silage, energy turnip, whole plants of cereals. Their production must be incorporated into crops rotation, whereby the ratio of raw material components is regulated by law (Makadi et al., 2012; Nkoa, 2014). The use the ADD in improving productive soil characteristics shows both positive and negative environmental impacts depending on the raw material used in the process, and the results were reviewed by Nkoa (2014). Efficiency of ADD as bio-fertilizer in many cases, according to literature data, is between those of livestock manure and mineral fertilizers (Simon et al., 2015; Popović et al., 2020). According to EU legislative digestate may be classified at three categories: "organic soil improver", "growing medium", and "organic, non-microbial plant biostimulant" but no "organic fertilizers" (Stürmer et al., 2020). However, in soil-plant system, including microorganisms, there are numerous processes and its controlling mechanisms leading to sometime controversy results of ADD effect on crop yield, so it is still open to question whether and to what extent it can replace the mineral fertilizer.

Sorghum (Sorghum bicolor L.) is an annual diploid species $(2 n=2 x=20)$ with a small genome $(\sim 730$ $\mathrm{Mb})$ and it is an agriculturally important short-day $\mathrm{C}_{4}$ plants. It is one of the world's five major food crops together with maize (Zea mays), rice (Oryza sativa), wheat (Triticum aestivum), and barley (Hordeum vulgare), and is the staple food for more than 500 million people worldwide (Paterson et al., 2009). Sorghum is agroenergy crop, highly adaptable to environmental stress. As a $\mathrm{C} 4$ species, it is characterized by high productivity and high efficiency of water and nitrogen use (Garofalo and Rinaldi, 2013; Ikanović et al., 2011), allowing cultivation on arid areas and degraded, salted and marginal soils, with what it excluded the competition for food production on fertile agricultural lands (Lakic et al., 2018). Sweet sorghum can be used for ethanol and biodiesel production while fodder sorghum is appropriate for biogas production in $\mathrm{AD}$ process (Ameen et al., 2017; Wanaasek et al., 2017).

The circular economy (CE) and the bioeconomy (BE) have become alternative economic production models (EPMs) that are essential to promote sustainable growth and development. The main goal of both models is to achieve a synergy between the economy, the environment, and society (Duque-Acevedo et al., 2020).

The aim of the research was to determine the efficiency of the digestate on the fodder sorghum production on moderately degraded and fertile agricultural land in case of biogas plant in Banat region of Republic of Serbia. Therefore, the present study was carried out to obtain information about the use of digestate in providing sorghum biomass on accessible land that enables sustainable biogas production. 


\section{Materials and Methods}

\section{Experimental design}

The experiments were conducted at two locations in Banat region, Republic of Serbia. L1- Ilandza $\left(45^{\circ} 16^{\prime} 77^{\prime \prime} \mathrm{N} ; 20^{\circ} 92^{\prime} 13^{\prime \prime} \mathrm{E}, 59\right.$ alt), calcic gleysol, was chosen because it is nearest the biogas plant which in the $\mathrm{AD}$ process uses $80,000 \mathrm{t}^{-1}$ of raw material - silage, biomass and manure and it produces, as by product, 16000 $\mathrm{t}^{-1}$ of digestate. L2 - Dolovo ( $44^{\circ} 90^{\prime \prime} 80^{\prime \prime} \mathrm{N} ; 20^{\circ} 83^{\prime \prime} 81$ " E, 71 alt), chernozem, is located at a distance of about $69 \mathrm{~km}$, which is close to the limit of profitability, from aspect of AD plant raw material. The hybrid of fodder sorghum, "Bulldozer" (KWS), was sown in last ten days of April, with a density of $30 \mathrm{~kg} \mathrm{ha}^{-1}$ seed (about 250,000 plants $\mathrm{ha}^{-1}$ ), after standard, pre-sowing preparation, without applying of mineral fertilizers. Field experiments were placed as a random block system in 10 repetitions on each of the locations, with the size of the basic plots $10 \mathrm{~m}^{2}(5 \mathrm{~m} \times 2 \mathrm{~m})$ in two variants: 1$)$ without digestate - control (C) and 2) with the digestate (50 $\left.\mathrm{t} \mathrm{ha}^{-1}\right)$ brought in into the land just before sowing - digestate (ADD). In both variants, $115 \mathrm{~kg} \mathrm{~N} \mathrm{ha}^{-1}(250 \mathrm{~kg}$ $\mathrm{ha}^{-1}$ urea with $46 \% \mathrm{~N}$ ) were inserted into the soil. Mowing of sorghum was carried out at the beginning of the tassel phase (the second decade of July) with a water content of $28-33 \%$. By the random sample method, it was chosen 10 plants from each plot and their height PH (m) and the numbers of leaves per steam (NL) were measured. The biomass was dried to constant weight and yields of dry biomass (BY) from each elementary plot were measured and converted to $t \mathrm{th}^{-1}$. Composite samples of sorghum silage obtained from all basic plots per variant were collected each year and locality. The biogas yield (BGY) was measured by VDI 4630 method (Pham et al., 2013) and calculated as $\mathrm{Nm}^{3} \mathrm{t}^{-1}$.

\section{Agrochemical analyses}

Soil samples were collected before field experiment establishment by sampling probe as undisturbed soil samples from ten randomly selected points per elementary plot (within a diameter of $3 \mathrm{~m}, 0-30 \mathrm{~cm}$ deep), and were transported in plastics bags as mixed samples about $1 \mathrm{~kg}$ (Popović et al., 2020a) and tested soil by Spalević et al. (2020). The soil samples were dried at room temperature and oven at $40^{\circ} \mathrm{C}$ before were grinded in a mill. Properties of ADD and/or soil was analysed: moisture content (SPRS ISO 11465-2002), dry matter (SPRS EN 15934), organic matter (after Tyurin), C-org was calculated using factor 1.724 (Nelson and Sommers 1996). The content of $\mathrm{N}$-tot is determined by Kjeldahl method (SPRS ISO 13878-2005) and the content of $\mathrm{P}_{2} \mathrm{O}_{5}$ and $\mathrm{K}_{2} \mathrm{O}$ (AL method by Egner-Riehm), $\mathrm{pH}$ and electrical conductivity (EC) were determined according SRPS ISO 10390:2007 and $\mathrm{CaCO}_{3}$ content by SRPS ISO 10693: 2005 method.

\section{Statistical analysis}

Statistica 12 for Windows was used for statistical analyses. All significance estimates were performed based on the F-test and the LSD-test for a level of significance of 5\% and 1\%. The relative dependence was determined by the correlation analysis method (Pearson correlation coefficients), and the obtained coefficients were tested with the $t$-test for the significance level of $5 \%$ and $1 \%$.

\section{Environmental variables}

Climate in Banat is moderately continental. Based on the data of meteorological stations: Pancevo (for locality Dolovo) and Vrsac (for locality Ilandza) in the years in which the researches were carried out, differed from the long-term average characteristic of the area (Table 1).

The average air temperature was lower than the annual average by $2.5^{\circ} \mathrm{C}$ in 2016 , by $1.0^{\circ} \mathrm{C}$ in 2017 and by $0.8^{\circ} \mathrm{C}$ in 2018 on L1 locality and by $2.8^{\circ} \mathrm{C}$ in 2016 , by $0.5^{\circ} \mathrm{C}$ in 2017 and by $0.8^{\circ} \mathrm{C}$ in 2018 on L2 locality (Table 1).

The tested locations differ in temperature during the vegetative periods, while the precipitation was unevenly distributed in space and time (Table 1). The total amounts of rainfall were above the perennial average in the surveyed growing seasons (2015, 2016 and 2017). Variable and moderately warm weather, with less 
precipitation than average, marked June 2016 and 2017. In 2018, precipitation was higher than the multi-year average by $41.1 \mathrm{~mm}$ on L1 locality and $48.7 \mathrm{~mm}$ on L2 locality (Table 1 ).

\section{Soil properties and digestate characteristics}

The investigated soils were neutral, weakly to medium carbonate, with a high content of organic C, moderately nitrogen content, highly supplied with phosphorus and potassium, EC is higher on L1 than on L2, but within acceptable limits (Table 2).

Table 1. Weather characteristics of the vegetative period: average monthly air temperature $\left({ }^{\circ} \mathrm{C}\right)$ and precipitation $(\mathrm{mm})$ and perennial average for locations L1 - Ilandza and L2 Dolovo

\begin{tabular}{|c|c|c|c|c|c|c|c|c|c|c|c|}
\hline \multicolumn{2}{|c|}{ Parameters } & \multicolumn{4}{|c|}{ Temperature $\left({ }^{\circ} \mathrm{C}\right)$} & \multicolumn{4}{c|}{ Precipitations $(\mathrm{mm})$} \\
\hline Year & Location & IV & V & VI & VII & $\bar{x}$ & IV & V & VI & VII & Total \\
\hline \multirow{2}{*}{2016} & L1 Calcic gleysol & 12.7 & 18.8 & 20.1 & 16.5 & 17.0 & 23.5 & 91.5 & 22.5 & 7.0 & 144.5 \\
\cline { 2 - 14 } & L2 Chernozem & 12.4 & 17.5 & 20.1 & 16.4 & 16.6 & 41.0 & 133.7 & 57.5 & 18.6 & 250.8 \\
\hline \multirow{2}{*}{2017} & L1 Calcic gleysol & 13.4 & 17.1 & 20.3 & 23.1 & 18.5 & 40.8 & 70.3 & 74.3 & 60.8 & 246.2 \\
\cline { 2 - 13 } & L2 Chernozem & 12.2 & 18.1 & 19.8 & 23.5 & 18.4 & 41.5 & 100.7 & 74.5 & 28.6 & 245.3 \\
\hline \multirow{2}{*}{2018} & L1 Calcic gleysol & 12.4 & 18.1 & 20.0 & 24.1 & 18.7 & 50.8 & 110.3 & 78.3 & 61.8 & 301.2 \\
\cline { 2 - 12 } & L2 Chernozem & 12.0 & 18.3 & 19.4 & 24.7 & 18.6 & 61.5 & 112.7 & 74.9 & 59.6 & 308.7 \\
\hline \multirow{2}{*}{$\begin{array}{c}\text { Long-term } \\
\text { average }\end{array}$} & L1 Calcic gleysol & 13.5 & 18.0 & 22.2 & 24.1 & 19.5 & 43.8 & 83.6 & 82.8 & 49.9 & 260.1 \\
\cline { 2 - 11 } & L2 Chernozem & 13.4 & 18.0 & 22.0 & 24.0 & 19.4 & 44.0 & 83.0 & 83.0 & 50.0 & 260.0 \\
\hline
\end{tabular}

Table 2. Agrochemical characteristics of soil

\begin{tabular}{|c|c|c|c|c|c|c|c|}
\hline \multirow{2}{*}{ Locality } & \multirow{2}{*}{$\begin{array}{l}\mathrm{pH} \\
\mathrm{KCl}\end{array}$} & \multirow{2}{*}{$\begin{array}{l}C_{\text {org }} \\
(\%)\end{array}$} & \multirow{2}{*}{$\begin{array}{l}\mathrm{N}_{\text {tot }} \\
(\%)\end{array}$} & $\mathrm{P}_{2} \mathrm{O}_{5}$ & $\mathrm{~K} 2 \mathrm{O}$ & \multirow{2}{*}{$\begin{array}{c}\mathrm{CaCO}_{3} \\
(\%)\end{array}$} & \multirow{2}{*}{$\begin{array}{c}\mathrm{EC} \\
\left(\mathrm{mS} \mathrm{cm}^{-1}\right)\end{array}$} \\
\hline & & & & \multicolumn{2}{|c|}{$\left(\mathrm{mg} \mathrm{100g^{-1 } )}\right.$} & & \\
\hline L1 & $6.95 \pm 0.30$ & $3.62 \pm 1.65$ & $0.14 \pm 0.04$ & $39.53 \pm 0.20$ & $38.01 \pm 0.22$ & $2.04 \pm 0.46$ & $1.61 \pm 0,16$ \\
\hline L2 & $7.00 \pm 0.10$ & $4.02 \pm 0.55$ & $0.20 \pm 0.02$ & $40.00 \pm 0.6$ & $34.13 \pm 0.08$ & $2.86 \pm 0.12$ & $0.72 \pm 0.04$ \\
\hline
\end{tabular}

Note: The values presented are average of three chemical repetitions \pm SE

Differences between locations were not reflected in the extent to which different soil productivity. The composition of the digestate that was applied is shown in Table 3.

Table 3. Agrochemical characteristics of digestate, 2016-2017

\begin{tabular}{|c|c|c|c|c|c|c|}
\hline Digestate & $\begin{array}{c}\text { Moisture } \\
\text { content }(\%)\end{array}$ & $\begin{array}{c}\text { Dry matter } \\
(\%)\end{array}$ & $\begin{array}{c}\mathrm{C}_{\text {org }} \\
(\%)\end{array}$ & $\begin{array}{c}\mathrm{N}_{\text {tot }} \\
(\%)\end{array}$ & $\begin{array}{c}\mathrm{P}_{\text {Egner }} \\
\left(\mathrm{g} \mathrm{kg}^{-1}\right)\end{array}$ & $\begin{array}{c}\mathrm{K}_{\text {Egner }} \\
\left(\mathrm{g} \mathrm{kg}^{-1}\right)\end{array}$ \\
\hline 2016 & 87.31 & 12.69 & 4.27 & 0.60 & 0.48 & 0.20 \\
\hline 2017 & 87.71 & 12.29 & 4.05 & 0.49 & 0.17 & 0.19 \\
\hline 2018 & 87.62 & 12.38 & 4.13 & 0.53 & 0.31 & 0.19 \\
\hline Average & 87.55 & 12.45 & 4.15 & 0.54 & 0.32 & 0.19 \\
\hline
\end{tabular}

The dry matter content has not changed significantly because it is primarily due to the digester type. The content of $\mathrm{N}, \mathrm{P}$ and $\mathrm{K}$ was different depending on the raw material used to produce biogas: silage (maize, wheat and sorghum) together with manure (pork and beef manure) in different relationships. 


\section{Results}

\section{Statistical analyses of sorghum productivity parameters}

Impact of the year and ADD, as well as their interaction on the tested properties of sorghum is shown in Table 4. Based on the analysis of variance, it can be concluded that the sorghum plant height very significantly affects locality $\left(F \exp =14.25^{* *}\right)$, variant $\left(F \exp =12.36^{* *}\right)$, and significantly affects year $(F \exp =$ $\left.0.73^{*}\right)$ and interaction $\mathrm{VxL}\left(\mathrm{Fexp}=0.83^{*}\right), \mathrm{YxL}\left(\mathrm{Fexp}=0.73^{*}\right)$ and $\mathrm{LxYxV}\left(\mathrm{Fexp}=1.54^{*}\right)$. On the number of leaves very significantly affects locality $\left(\mathrm{Fexp}=14.26^{* *}\right)$, variant $\left(\mathrm{Fexp}=12.38^{* *}\right)$, and significantly affected year $\left(F \exp =0.74^{*}\right)$ while the interaction of the examined factors was not significant.

On the biomass yield of sorghum plants very significantly affects locality $\left(\mathrm{Fexp}=107.12^{* *}\right.$ ), variant $\left(\mathrm{Fexp}=60.34^{* *}\right)$ and significantly affects year $\left(\mathrm{Fexp}=7.84^{*}\right)$ and $\mathrm{LxYxV}$ interaction $\left(\mathrm{Fexp}=2.27^{*}\right)$. On biogas yield very significantly affects locality $\left(\mathrm{Fexp}=51.10^{* *}\right)$, variant $\left(\mathrm{Fexp}=70.82^{* *}\right)$, and significantly affects year $\left(\mathrm{Fexp}=70.82^{*}\right)$ and $\mathrm{LxYxV}$ interaction $\left(\mathrm{Fexp}=6.52^{*}\right)$, Table 4 .

\section{Sorghum biomass yield}

The influence of ADD on sorghum parameters (NL, PH, BY) over three years (2016-2018) at two sites is shown in Table 5 . Samples are homogeneous $(0.64 \%<\mathrm{CV}<21.94 \%)$. The number of leaves per plant, $\mathrm{C}=$ 10.33 is lower in relation to $\mathrm{ADD}=13.28,(\mathrm{p}<0.05)$, the difference is $2.95(28.56 \%)$. Higher plant height was measured on $\mathrm{L} 2=2.96 \mathrm{~m}$, compared to $\mathrm{L} 1=2.81 \mathrm{~m},(\mathrm{p}<0.01)$. ADD amendment showed a significant positive effect: $\mathrm{C}=2.81 \mathrm{~m}$ and $\mathrm{ADD}=2.96 \mathrm{~m}(\mathrm{p}<0.05)$, the difference is $0.15 \mathrm{~m}(5.34 \%)$.

Biomass yield (DM, first mowing) was the highest in $2018\left(41.74 \mathrm{t} \mathrm{ha}^{-1}\right)$ on chernozem (L2) with the use of ADD. The yield of biomass is lower $\mathrm{C}=38.60 \mathrm{t} \mathrm{ha}^{-1}$ in relation to ADD $=39.96 \mathrm{t} \mathrm{ha}^{-1}$, the difference is $1.36 \mathrm{t} \mathrm{ha}^{-1}(3.40 \%)(\mathrm{p}<0.01)$. In Ilandza, L1 $=37.90 \mathrm{t} \mathrm{ha}^{-1}$, the yield of biomass is lower than Dolovo, L2 = $39.96 \mathrm{t} \mathrm{ha}^{-1}(\mathrm{p}>0.01)$.

Table 4. Interaction of the variant of the experiment and biomass of sorghum

\begin{tabular}{|c|c|c|c|c|c|c|c|c|}
\hline Para & eter & Variant & Year & Locality & $Y \& V$ & $V \& L$ & $\mathrm{Y} \& \mathrm{~L}$ & Y\&V\&L \\
\hline \multicolumn{9}{|c|}{ Plant height, $\mathrm{PH}$} \\
\hline Test & $\mathrm{F}$ & $12.36^{* *}$ & $0.73^{*}$ & $14.25^{* *}$ & $0.05^{\mathrm{ns}}$ & $0.83^{*}$ & $0.73^{*}$ & $1.54^{*}$ \\
\hline \multirow{2}{*}{ LSD } & 0.5 & 0.088 & 0.108 & 0.088 & 0.153 & 0.125 & 0.153 & 0.216 \\
\hline & 0.1 & 0.119 & 1.146 & 0.119 & 0.207 & 0.169 & 0.207 & 0.293 \\
\hline \multicolumn{9}{|c|}{ No of leaf, NL } \\
\hline Test & $\mathrm{F}$ & $12.38^{* *}$ & $0.74^{\mathrm{ns}}$ & $14.26^{* *}$ & $0.95^{\mathrm{ns}}$ & $0.37^{\mathrm{ns}}$ & $0.49^{\text {ns }}$ & $0.23^{\mathrm{ns}}$ \\
\hline \multirow{2}{*}{ LSD } & 0.5 & 1.180 & 1.454 & 1.180 & 2.056 & 1.678 & 2.056 & 2.907 \\
\hline & 0.1 & 1.608 & 1.969 & 1.608 & 2.773 & 2.274 & 2.773 & 3.939 \\
\hline \multicolumn{9}{|c|}{ Biomass yield, BY } \\
\hline Test & $\mathrm{F}$ & $60.37^{* *}$ & $7.84^{*}$ & $107.12^{* *}$ & $0.16^{\mathrm{ns}}$ & $0.17^{\mathrm{ns}}$ & $0.27^{\mathrm{ns}}$ & $2.27^{*}$ \\
\hline \multirow{2}{*}{ LSD } & 0.5 & 0.783 & 0.959 & 0.783 & 1.356 & 1.107 & 1.356 & 1.917 \\
\hline & 0.1 & 1.061 & 1.299 & 1.061 & 1.837 & 1.499 & 1.837 & 2.598 \\
\hline \multicolumn{9}{|c|}{ Biogas yield, BGY } \\
\hline Test & $\mathrm{F}$ & $70.82^{* *}$ & $8.30^{*}$ & $51.10^{* *}$ & $0.58^{\text {ns }}$ & $1.28^{\text {ns }}$ & $6.52^{*}$ & $0.93^{\mathrm{ns}}$ \\
\hline \multirow{2}{*}{ LSD } & 0.5 & 2.814 & 3.440 & 2.814 & 4.873 & 3.979 & 4.874 & 6.888 \\
\hline & 0.1 & 3.803 & 4.641 & 3.803 & 6.586 & 2.779 & 6.587 & 9.309 \\
\hline
\end{tabular}




\section{Sorghum biogas yield}

Average biogas yield (BGY) was $147.68 \mathrm{Nm}^{3} \mathrm{t}^{-1}, 154.45 \mathrm{Nm}^{3} \mathrm{t}^{-1}$ and $151.74 \mathrm{Nm}^{3} \mathrm{t}^{-1}$ during 2016, 2017 and 2018 respectively.

Table 5. Influence of the locality (L1 Ilandza, calcic gleysol; L2 Dolovo, L2 chernozem) year and digestate on sorghum biomass yield BY ( $\left.\mathrm{t} \mathrm{DM} \mathrm{ha}^{-1}\right)$ and yield components, number of leaves per steam NL and plant height PH (average +/- SE)

\begin{tabular}{|c|c|c|c|c|c|c|c|}
\hline Locality & Variant & Parameter & 2016 & 2017 & 2018 & $\bar{x} \pm s_{\bar{x}}$ & $\mathrm{CV}$ \\
\hline \multirow{3}{*}{$\mathrm{L} 1$} & Control & \multirow{2}{*}{ NL } & $12.66 \pm 5.51$ & $8.66 \pm 0.57$ & $9.00 \pm 0.07$ & $10.11 \pm 3.37$ & 21.94 \\
\hline & Digestate & & $12.00 \pm 1.00$ & $14.00 \pm 1.00$ & $14.01 \pm 1.01$ & $13.33 \pm 1.32$ & 8.68 \\
\hline & \multicolumn{2}{|c|}{$\bar{x} \pm s_{\bar{x}}$} & $12.33 \pm 3.56$ & $11.33 \pm 3.01$ & $11.50 \pm 2.81$ & $11.72 \pm 2.98$ & 4.57 \\
\hline \multirow{3}{*}{$\mathrm{L} 2$} & Control & \multirow{2}{*}{ NL } & $10.33 \pm 0.57$ & $10.66 \pm 0.57$ & $10.67 \pm 0.57$ & $10.55 \pm 0.53$ & 1.83 \\
\hline & Digestate & & $13.33 \pm 0.57$ & $13.66 \pm 0.58$ & $12.66 \pm 0.57$ & $13.22 \pm 0.66$ & 3.85 \\
\hline & \multicolumn{2}{|c|}{$\bar{x} \pm s_{\bar{x}}$} & $11.83 \pm 1.72$ & $12.17 \pm 1.72$ & $11.67 \pm 1.21$ & $11.89 \pm 1.49$ & 2.15 \\
\hline \multicolumn{3}{|c|}{ Control Average } & $11.50 \pm 3.73$ & $9.67 \pm 1.21$ & $9.83 \pm 0.99$ & $10.33 \pm 2.33$ & 9.81 \\
\hline \multicolumn{3}{|c|}{ Digestate Average } & $12.67 \pm 1.03$ & $13.83 \pm 0.75$ & $13.33 \pm 1.03$ & $13.28 \pm 1.02$ & 4.38 \\
\hline \multicolumn{3}{|c|}{ Average } & $12.08 \pm 2.68$ & $11.75 \pm 2.38$ & $11.58 \pm 2.07$ & $11.80 \pm 2.33$ & 2.15 \\
\hline \multirow{3}{*}{$\mathrm{L} 1$} & Control & \multirow{2}{*}{$\mathrm{PH}(\mathrm{m})$} & $2.70 \pm 0.17$ & $2.70 \pm 0.10$ & $2.73 \pm 0.12$ & $2.71 \pm 0.12$ & 0.64 \\
\hline & Digestate & & $2.76 \pm 0.12$ & $2.97 \pm 0.12$ & $2.96 \pm 0.21$ & $2.90 \pm 1.17$ & 4.09 \\
\hline & \multicolumn{2}{|c|}{$\bar{x} \pm s_{\bar{x}}$} & $2.78 \pm 0.17$ & $2.82 \pm 0.15$ & $2.83 \pm 0.15$ & $2.81 \pm 0.14$ & 0.94 \\
\hline \multirow{3}{*}{ L2 } & Control & \multirow{2}{*}{$\mathrm{PH}(\mathrm{m})$} & $2.87 \pm 0.15$ & $2.93 \pm 0.06$ & $2.93 \pm 0.12$ & $2.96 \pm 0.11$ & 1.28 \\
\hline & Digestate & & $3.07 \pm 0.12$ & $3.00 \pm 0.10$ & $3.00 \pm 0.10$ & $3.02 \pm 0.10$ & 1.25 \\
\hline & \multicolumn{2}{|c|}{$\bar{x} \pm s_{\bar{x}}$} & $2.91 \pm 0.19$ & $2.98 \pm 0.09$ & $2.98 \pm 0.15$ & $2.96 \pm 0.15$ & 1.48 \\
\hline \multicolumn{3}{|c|}{ Control Average } & $2.78 \pm 0.17$ & $2.82 \pm 0.15$ & $2.83 \pm 0.15$ & $2.81 \pm 0.15$ & 0.94 \\
\hline \multicolumn{3}{|c|}{ Digestate Average } & $2.92 \pm 0.19$ & $2.98 \pm 0.09$ & $2.98 \pm 0.15$ & $2.96 \pm 0.15$ & 1.17 \\
\hline \multicolumn{3}{|c|}{ Average } & $2.85 \pm 0.19$ & $2.90 \pm 0.15$ & $2.90 \pm 0.16$ & $2.89 \pm 0.16$ & 1.27 \\
\hline \multirow{3}{*}{ L1 } & Control & \multirow{2}{*}{$\mathrm{BY}\left(\mathrm{t} \mathrm{ha} \mathrm{a}^{-1}\right)$} & $36.19 \pm 0.67$ & $36.12 \pm 0.43$ & $37.10 \pm 0.42$ & $36.47 \pm 0.66$ & 1.49 \\
\hline & Digestate & & $39.18 \pm 0.64$ & $37.38 \pm 2.24$ & $36.36 \pm 0.67$ & $38.64 \pm 1.55$ & 2.83 \\
\hline & \multicolumn{2}{|c|}{$\bar{x} \pm s_{\bar{x}}$} & $37.84 \pm 1.88$ & $37.31 \pm 1.34$ & $38.54 \pm 1.60$ & $37.90 \pm 1.60$ & 1.62 \\
\hline \multirow{3}{*}{$\mathrm{L} 2$} & Control & \multirow{2}{*}{$\mathrm{BY}\left(\mathrm{t} \mathrm{ha}^{-1}\right)$} & $39.50 \pm 0.34$ & $38.50 \pm 0.18$ & $39.97 \pm 0.14$ & $39.33 \pm 0.55$ & 1.91 \\
\hline & Digestate & & $40.04 \pm 0.42$ & $41.05 \pm 0.58$ & $41.74 \pm 0.45$ & $41.28 \pm 0.55$ & 1.01 \\
\hline & \multicolumn{2}{|c|}{$\bar{x} \pm s_{\bar{x}}$} & $40.11 \pm 1.13$ & $39.21 \pm 2.49$ & $40.56 \pm 1.39$ & $39.96 \pm 1.78$ & 1.71 \\
\hline \multicolumn{3}{|c|}{ Control Average } & $37.85 \pm 1.88$ & $37.31 \pm 1.34$ & $38.54 \pm 1.60$ & $38.60 \pm 1.63$ & 1.62 \\
\hline \multicolumn{3}{|c|}{ Digestate Average } & $40.11 \pm 1.13$ & $39.21 \pm 2.49$ & $40.55 \pm 1.40$ & $39.96 \pm 1.78$ & 1.71 \\
\hline \multicolumn{3}{|c|}{ Average } & $39.96 \pm 1.78$ & $38.26 \pm 2.78$ & $39.54 \pm 1.78$ & $38.93 \pm 1.96$ & 1.65 \\
\hline & Control & BGY & $132.67 \pm 10.88$ & $143.27 \pm 1.22$ & $143.67 \pm 4.09$ & $139.87 \pm 7.8$ & 4.46 \\
\hline $\mathrm{L} 1$ & Digestate & $\left(\mathrm{Nm}^{3} \mathrm{t}^{-1}\right)$ & $146.00 \pm 6.63$ & $160.27 \pm 0.70$ & $152.53 \pm 4.23$ & $152.93 \pm 7.3$ & 4.67 \\
\hline & & & $139.33 \pm 10.87$ & $151.77 \pm 9.35$ & $148.10 \pm 5.88$ & $146.4 \pm 9.97$ & 4.37 \\
\hline & Control & BGY & $151.23 \pm 0.86$ & $152.30 \pm 1.74$ & $150.06 \pm 1.15$ & $151.2 \pm 1.48$ & 0.74 \\
\hline L2 & Digestate & $\left(\mathrm{Nm}^{3} \mathrm{t}^{-1}\right)$ & $160.80 \pm 1.37$ & $162.00 \pm 1.74$ & $160.70 \pm 0.62$ & $161.17 \pm 1.3$ & 0.45 \\
\hline & & & $156.17 \pm 5.34$ & $157.15 \pm 5.54$ & $155.38 \pm 5.88$ & $156.18 \pm 5.3$ & 0.57 \\
\hline & Control ave & & $141.95 \pm 9.88$ & $147.78 \pm 1.14$ & $146.87 \pm 2.60$ & $145.53 \pm 4.1$ & 3.62 \\
\hline & Digestate ave & & $153.40 \pm 5.83$ & $161.14 \pm 1.49$ & $156.61 \pm 2.40$ & $157.1 \pm 3.78$ & 2.71 \\
\hline & Average & & $147.68 \pm 11.94$ & $154.45 \pm 7.84$ & $151.74 \pm 6.77$ & $151.29 \pm 9.3$ & 2.25 \\
\hline
\end{tabular}

In all variants of the experiment, ADD induced an increase in yield that was higher on gleysol than chernozem. In first year of investigation the biogas yield was significantly lower than in following years. Significantly BGY was measured $156.18 \mathrm{Nm}^{3} \mathrm{t}^{-1}$ on L2 (chernozem) compared with L1 (calcic gleysol) 146.40 
$\mathrm{Nm}^{3} \mathrm{t}^{-1},(\mathrm{p}<0.01)$ and with digestate $157.10 \mathrm{Nm}^{3} \mathrm{t}^{-1}$ compared to control $145.53 \mathrm{Nm}^{3} \mathrm{t}^{-1}(\mathrm{p}<0.05)$ (Figure 1.). The effect of digestate was $11.52 \mathrm{Nm}^{3} \mathrm{t}^{-1}(7.92 \%)$.

The cultivation site showed a statistically significant effect on biogas yield. Statistically significantly higher biogas yield was measured at the second locality, in Dolovo, L2 $=156.18 \mathrm{Nm}^{3} \mathrm{t}^{-1}$, in relation to the first locality (Ilindza), $\mathrm{L} 1=146.40 \mathrm{Nm}^{3} \mathrm{t}^{-1},(\mathrm{p}<0.01)$. The LxY factor interaction had a statistically significant effect on biogas yield.

Considering the biomass produced (fresh weight with $\sim 30 \%$ water content) there are maximal biogas production $9582 \mathrm{Nm}^{3} \mathrm{ha}^{-1}$ on L2+ADD during 2018, minimal $6859 \mathrm{Nm}^{3} \mathrm{ha}^{-1}$ during 2018 on L1 control. Average BGY for 3 years were 7134, 8440, 8493 and $9503 \mathrm{Nm}^{3} \mathrm{ha}^{-1}$ for Control L1, ADD L1, Control L2 and ADD L2, respectively.

Sorghum number of leaves per steam - NL

Average number of leaves per steam (NL) was 12.08, 11.75 and 11.58 during 2016, 2017 and 2018 respectively.

In all variants of the experiment, $\mathrm{ADD}$ induced an increase in NL that was higher on chernozem than gleysol. Significantly NL was measured 11.89 on L2 (chernozem) compared with L1 (calcic gleysol) 11.72 and with digestate 13.28 compared to control 10.33 ( $\mathrm{p}<0.05$ ) (Figure 1.). The effect of digestate was $12.28 \%$.

\section{Sorghum number of plant height - $P H$}

Average number of plant height (PH) was $2.85 \mathrm{~m}, 2.90 \mathrm{~m}$ and $2.90 \mathrm{~m}$ during 2016, 2017 and 2018 respectively.

In all variants of the experiment, ADD induced an increase in $\mathrm{PH}$ that was higher on chernozem than gleysol. In first year of investigation the PH was lower than in following years. Significantly PH was measured $2.96 \mathrm{~m}$ on L2 (chernozem) compared with L1 (calcic gleysol) 2.81 and with digestate 2.96 compared to control $2.81(\mathrm{p}<0.05)$ (Figure 1.). The effect of digestate was 5.34\%.

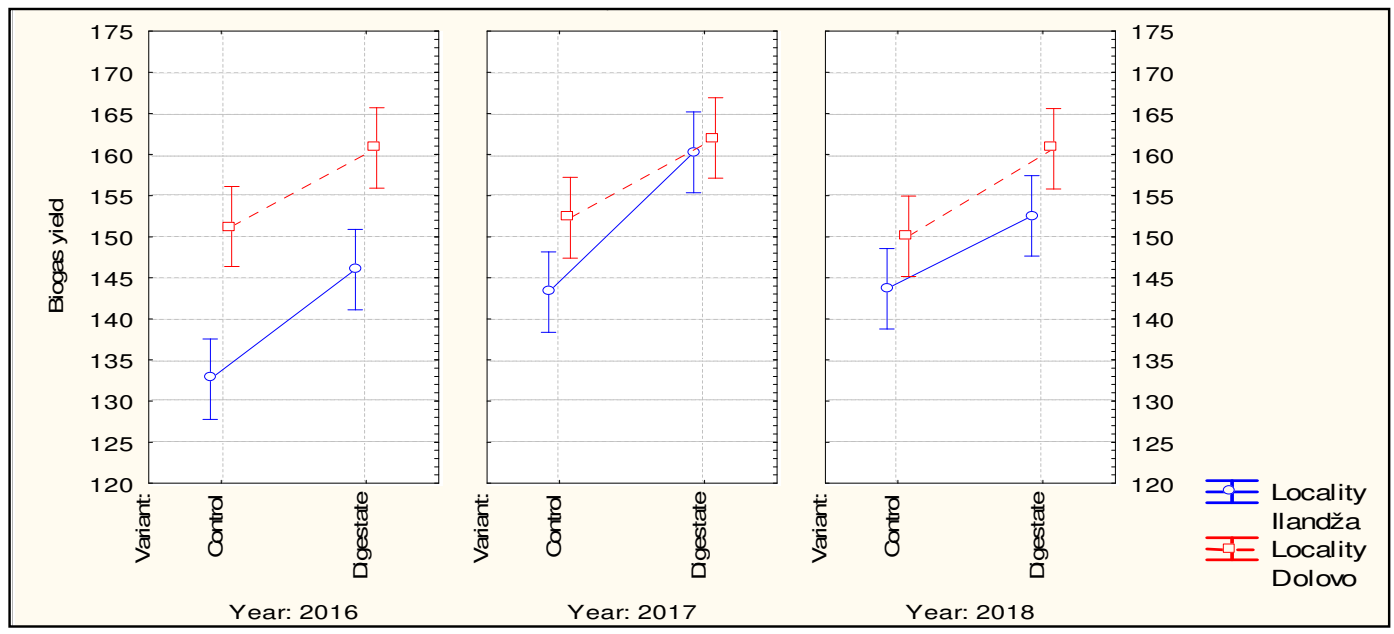

Figure 1. Influence of the locality, year and digestate on biogas yield $\left(\mathrm{Nm}^{3} \mathrm{t}^{-1}\right)$

\section{Correlations of tested parameters}

The results of the relative dependence of the examined sorghum indicators expressed by the Pearson correlation coefficient are shown in Table 6. Biomass yield was in positive and statistically significant dependence with cultivation locality $\left(\mathrm{r}=0.71^{* *}\right)$, biogas yield $\left(\mathrm{r}=0.68^{* *}\right)$ and precipitation $\left(\mathrm{r}=0.61^{* *}\right)$ and in positive statistically significant dependence with digestate $\left(\mathrm{r}=0.53^{*}\right)$ and plant height $\left(\mathrm{r}=0.59^{*}\right)$, Table 6 . 
Table 6. Correlations of tested parameters

\begin{tabular}{|c|c|c|c|c|c|c|c|c|c|}
\hline Parameter & $\mathrm{V}$ & $\mathrm{Y}$ & $\mathrm{L}$ & $\mathrm{BY}$ & $\mathrm{NL}$ & $\mathrm{PH}$ & $\mathrm{BGY}$ & $\mathrm{T}$ & $\mathrm{P}$ \\
\hline Biomass yield & $0.53^{*}$ & $0.12^{\mathrm{ns}}$ & $0.71^{* *}$ & 1.00 & $0.32^{\mathrm{ns}}$ & $0.59^{*}$ & $0.68^{* *}$ & $0.14^{\mathrm{ns}}$ & $0.61^{* *}$ \\
\hline Number of leaves & $0.64^{* *}$ & $-0.09^{\mathrm{ns}}$ & $0.04^{\mathrm{ns}}$ & $0.32^{\mathrm{ns}}$ & 1.00 & $0.37^{*}$ & $0.43^{*}$ & $-0.03^{\mathrm{ns}}$ & $-0.03^{\mathrm{ns}}$ \\
\hline Plant height & $0.46^{*}$ & $0.15^{\mathrm{ns}}$ & $0.50^{*}$ & $0.59^{*}$ & $0.37^{*}$ & 1.00 & $0.59^{*}$ & $-0.08^{\mathrm{ns}}$ & $0.51^{*}$ \\
\hline Biogas yield & $0.63^{* *}$ & $0.18^{\mathrm{ns}}$ & $0.53^{*}$ & $0.68^{* *}$ & $0.43^{*}$ & $0.59^{*}$ & 1.00 & $0.61^{* *}$ & $-0.22^{\mathrm{ns}}$ \\
\hline
\end{tabular}

${ }^{n s}$ Stat. non-significant; ${ }^{*}$ and ${ }^{* *}$ significant at level of $\mathrm{p}<0.05$ and $\mathrm{p}<0.01, \mathrm{~V}$-Variant, Y -Year, L- Locality, BY -

Biomass yield, BGY- Biogas yield, NL - Number of leafs, PH- Plant height, T - Temperature; P - Precipitation

The number of leaves was in a positive, statistically very significant dependence with the fertilization variant $\left(\mathrm{r}=0.64^{* *}\right)$ and in a positive statistically significant dependence with the plant height $\left(\mathrm{r}=0.37^{*}\right)$. Plant height was in a positive statistically significant dependence with biomass yield $\left(\mathrm{r}=0.59^{*}\right)$, growing locality $\left(\mathrm{r}=0.50^{*}\right)$, precipitation $\left(\mathrm{r}=0.51^{*}\right)$, variant $\left(\mathrm{r}=0.46^{*}\right)$ and number of leaves $\left(\mathrm{r}=0.37^{*}\right)$. While plant height and number of leaves were negatively correlated with temperatures, but did not show a statistically significant dependence, Table 6.

Biogas yield was in positive, statistically very significant dependence with digestate $\left(\mathrm{r}=0.63^{* *}\right)$, biomass yield $\left(\mathrm{r}=0.68^{* *}\right)$ and temperatures $\left(\mathrm{r}=0.61^{* *}\right)$ and in positive statistically significant dependence with locality $\left(\mathrm{r}=0.53^{*}\right)$, plant height $\left(\mathrm{r}=0.59^{*}\right)$ and number of leaf $\left(\mathrm{r}=0.43^{*}\right)$.

\section{Discussion}

The concept of the circular economy aims to keep raw materials in a closed loop. Resources are maximally used, the need for new ones is reduced, waste is avoided and the life cycle of products is increased. In short, the waste of today becomes the raw material of tomorrow - the same as in nature. Circular economic production models of the circular economy (CEPMs), which include circular economy, bioeconomy, and circular bioeconomy, are among the main tools characterizing development policies in different countries. The management policies and strategies of the circular bioeconomy are key to promoting research focused on agricultural waste biomass (AWB) valorisation since bioenergy and/or biofuel production continue to be a priority (Duque-Acevedo et al., 2020).

\section{Effect of locations and digestate from sorghum production}

Slurry of AD process, digestate, has some beneficial properties and its proper exploitation could bring some advances to farmers (increase of crops yield), environment (better $\mathrm{N}$ usage efficiency) as well as biogas plant owner (disposition of large amounts of by-product) (Przygocka-Cyna and Grzebisz, 2020). Solid fraction of digestate can be directly applied into the field or composted and used as soil amendment which can be 2 to 3 times cheaper for the farmer than the fertilizer produced industrially. The lack of arable lands in the area surrounding the biogas plant is a real problem (Prask et al., 2018). In case of Republic of Serbia, there are only few biogas producing plants that began to work in the last five years, placed near significant areas of arable land. These plants can produce biomass for silage using digestate from $\mathrm{AD}$ process as fertilizer. In case of Ilandza there are 480 ha partially degraded arable land owned and 300 ha leased, close to AD reactor, on which sorghum production were compared with highly productive chernozem in Dolovo, with moderate distance. Transport distance is limited to a $50 \mathrm{~km}$ for feedstocks having high ( 70\% DM) and to $10 \mathrm{~km}$ for feedstock with low dry matter content, such as slurry (<10\% DM) for economics (Scarlat et al., 2018). In the immediate vicinity there are farms with which the power plant supplies manure. This manure has been applied at soil as bio-fertilizer before the biogas plant started potentially inducing large emissions of $\mathrm{CH}_{4}$.

Climate change has the potential to both positively and negatively affect the location, timing, and productivity of crop at local, national and global scales (Ikanović et al., 2018; Rakaščan et al., 2019; Rajičić et al., 2020a; Popović et al., 2019; 2020a; 2020b; Milanović et al., 2020). 


\section{Sorghum biomass yield}

The production of agri-energy crops on degraded or marginal soils with the use of a by-product from the energy conversion process enables a long-term convergence of SDGs. A challenge is the production of agrienergy crops on marginal land, when the site is closest to the biogas plant as is the case in Ilandza (L1). Over the past 60 years, intensive crop production with inadequate management (contempt of crop rotation, excessive fertilization with mineral fertilizers, over-watering of water with elevated salt content) has led to changes in the physical and chemical properties of the soil and to its salinity. Since the sorghum is suitable for such land (Lakic et al., 2018) and that it allows its remediation (Gelaye et al., 2019), it was selected for experiment.

Biochemical properties of digestate mostly depend on feedstock and the type - configuration of reactor (Przygocka-Cyna and Grzebisz, 2018). Organic matter content and relative rations $\mathrm{C} / \mathrm{N}$ are the main indicator that defines the status of soil amendment (Nkoa, 2014). In presented field experiment, with ADD application, about $200 \mathrm{~kg}$ of C-ha ${ }^{-1}$ was brought into the soil, $27 \mathrm{~kg} \mathrm{~N} \mathrm{ha}^{-1}, 1.6 \mathrm{~kg} \mathrm{P} \mathrm{ha}^{-1}$ and $9.8 \mathrm{~kg} \mathrm{~K} \mathrm{ha}^{-1}$. Added quantities $\mathrm{N}, \mathrm{P}$ and $\mathrm{K}$ are significantly lower than recommended for KWS sorghum hybrids. According to microbial degradability digestate can slowly release a high available nutrient content (N, P, K) (Tambone et al., 2010), which positive effects on the crop development (Mortola et al., 2019). It has recently been proven that the application of digestate in the production of corn for silage provides the same crop yield as the application of urea with the same nitrogen content, while emitting $23 \%$ more nitrogen oxides and $66 \%$ less ammonium when using digestate compared to urea (Verdi et al., 2019).

Biomass development, which was monitored through the usual attributes of plant height and number of leaves per tree at the examined locations, indicates that agroecological conditions were favorable for sorghum development so that yields exceeding average, even partially deradicated soil were achieved. Comparison of the obtained results (maximal biomas yeld $41.74 \mathrm{t} \mathrm{DM} \mathrm{ha}^{-1}$ on chernozem and $39.18 \mathrm{t} \mathrm{DM} \mathrm{ha}{ }^{-1}$ on gleysol with digestate) with the published is difficult because it is about different sorghum genotypes, different types of soil and climatic conditions. However, the achieved yields of biomass are in the rank of yield in Serbia, which were obtained under similar conditions, with the application of manure $25 \mathrm{t} \mathrm{ha}^{-1}+70 \mathrm{~kg} \mathrm{~N} \mathrm{ha}^{-1}+120-140 \mathrm{~kg} \mathrm{P} \mathrm{ha}$ + 120-140 kg P ha-1 (Jankovic et al., 2017) and higher than reported by Wannasek et al. (2017): DM biomass yield ranged between 15.7 and $20.67 \mathrm{t} \mathrm{ha}^{-1}$ when sorghum was grown as main crop, which concludes that sorghum can be used as side but also the main crop for biogas production. The impact of ADD on the biomass increase in three agri-energy crops, Sida hermaphrodita, Zea mays L. and Medicago sativa L. and the production of biogas, was the same as with the application of the recommended agricultural doses of NPK fertilizers (Barbosa et al., 2014).

For sustainable agriculture, an important parameter is the production of biogas per unit area of land used for the production of silage crops. Maize FAO group 300-600 allows the production of 7,500-10,200 $\mathrm{Nm}^{3}$ $\mathrm{ha}^{-1}$, while other cereals are in the range of 3,200-4,500 Nm $\mathrm{ha}^{-1}$ (Amon et al., 2007). In presented field experiment biogas production reach $9582 \mathrm{Nm}^{3} \mathrm{ha}^{-1}$ on chenozem with digestate amendment. The results are in accordance to results reported (De Meester et al., 2004; Zegada-Lizarazu and Monty, 2011) that mentioned that the maize silage is the best source of feedstock for biogas production according to energy efficiency, but it could be replaced by sorghum especially on partially degraded saline soils or in arid areas (Mekdad and Rady, 2016; Mahmood et al., 2015) due to its drought tolerance, easiness of cultivation and high yield. Maize-based silage has greater environmental impacts than sorghum due to more intensive cultivation, but manure-based $\mathrm{AD}$ process has lower impact than energy crops in reducing GHG emissions (Agostini et al., 2015).

\section{Sorghum biogas yield}

Biogas yield depends on sorghum cultivar, klimate and pedological characteristics, silage compositiom and biodegradation process. Obtained results are in range expected according to literature data (Mahmood et al., 2013; Hassan et al., 2018; Habyarimana et al., 2019). The yield of biogas produced from sorghum silage was higher from plots on chernozem than on gleysol, except in 2017 when they were equal. In all variants with 
the use of digestate, higher biogas yields were achieved in relation to the control, which indicates that ADD had a positive effect not only on the yield of sorghum biomass but also on its quality.

As an alternative nutrient source, $\mathrm{ADD}$ contributes to the mitigation of climate change through the reduction of greenhouse gas emissions, both directly (Hao et al., 2016) and indirectly through the production of nitrogenous mineral fertilizers. A system integrating production of biogas and electricity from renewable sources as agro-energy crops (silage sorghum) together with animal husbandry waste (manure) with production of this silage on marginal land using digestate from $\mathrm{AD}$ process as soil amendment leading to approaching low carbon agriculture and circular economy by recycling nutrients (Głab et al., 2019).

\section{Conclusions}

The use of digestate as fertilizer on land on which the agri-energy crop is dedicated produced as raw materials for energy conversion in the process of anaerobic digestion leads to the decarbonisation of agriculture, the use of renewable energy sources and increasing the profitability of the biogas power plant. Amounts of the biomass and biogas produced in field experiment indicated that sorghum is suitable raw material for the codigestion with manure. Obtained results indicated a strong positive effect of ADD on forage sorghum biomass development, especially number of leaves, booth on calcic gleysol and chernozem type of soil. Biomass yield of sorghum produced with digestate amendment reach amounts reported for sorghum produced with application of manure+mineral fertilizer. Biogas yield produced from sorghum silage is close to amounts reported for maize.

Future investigations of soil physical, chemical and biological properties of soil are necessary for explanation of more pronounced digestate amendment effect on fertile than on partially degraded soil.

\section{Authors' Contributions}

Conceptualization: GD and JM; Data curation NR, VP, JI; Formal analysis VP and MAR; Funding acquisition GD; Investigation NR; Methodology NR; Project administration VP; Resources JM; Software VP and MAR; Supervision LJZ; Validation JI; Visualization TM; Writing - original draft VP, TM, and LJZ; Writing - review and editing GD. All authors read and approved the final manuscript.

\section{Acknowledgements}

This research was supported by the Ministry of Education, Science and Technological Development of the Republic of Serbia No 0801-417/1 and grant numbers: 451-03-9/2021-14/200032 and 200116 and Bilateral Project Serbia and Montenegro, 2019-2021: Alternative cereals and oil crops as a source of healthcare food and an important raw material for the production of biofuel.

\section{Conflict of Interests}

The authors declare that there are no conflicts of interest related to this article. 


\section{References}

Agostini A, Battini F, Guintoli J, Zabaglio V, Padella M, Baxter D, ... Amaduci S (2015). Environmentally sustainable biogas? The key role of maize co-digestion with energy crops. Energies 8:5234-5265. https://doi.org/10.3390/en8065234

Ameen A, Yang X, Chen F, Tang C, Du F, Fahad S, Hui Xie G (2017). Biomass yield and nutrient uptake of energy sorghum in response to nitrogen fertilizer rate on marginal land in a semi-arid region. Bioenergy Resources 10:363-376. https://doi.org/10.1007/s12155-016-9804-5

Amon T, Amon B, Kryvoruchko V, Machmüller A, Hopfner-Sixt K, Bodiroza V, ... Zollitschf W (2007). Methane production through anaerobic digestion of various energy crops grown in sustainable crop rotations. Bioresource Technology 98(17):3204-3212. https://doi.org/10.1016/j.biortech.2006.07.007

Barbosa D, Nabel M, Jablonowski N D (2014). Biogas-digestate as nutrient source for biomass production of Sida hermaphrodita, Zea mays L. and Medicago sativa L. Energy Procedia 59:120-126. https://doi.org/10.1016/j.egypro.2014.10.357

De Meester S, Demeyer J, Velghe F, Peene A, Van Langenhove H, Dewulf J (2012). The environmental sustainability of anaerobic digestion as a biomass valorization technology. Bioresource Technology 121:396-403. https://doi.org/10.1016/j.biortech.2012.06.109

Duque-Acevedo M, Belmonte-Ureña LJ, Yakovleva N, Camacho-Ferre F (2020). Analysis of the circular economic production models and their approach in agriculture and agricultural waste biomass management. Journal of Environmental Research and Public Health 17:9549. https://doi.org/10.3390/ijerph17249549

European Parliament (2009). Directive 2009/28/EC. Promotion of the use of energy from renewable sources and amending and subsequently repealing Directives 2001/77/EC and 2003/30/EC. O. J. European Union 140(16). http://data.europa.eu/eli/dir/2009/28/2015-10-05

Garofalo P, Rinaldi M (2013). Water-use efficiency of irrigated biomass sorghum in a Mediterranean environment. Spanish Journal of Agricultural Research 11:1153-1169.

Gelaye KK, Zehetner F, Loiskandl W, Klik A (2019). Comparison of growth of annual crops used for salinity bioremediation in the semi-arid irrigation area. Plant Soil Environment 65:165-171. https://doi.org/10.17221/499/2018-PSE

Głab L, Sowinski J (2019). Sustainable production of sweet sorghum as a bioenergy crop using biosolids taking into account greenhouse gas emissions. Sustainability 11:3033-3050. https://doi.org/10.3390/su11113033

Habyarimana E, Piccard I, Catellani M, De Franceschi P, Dall'agata M (2019). Towards predictive modeling of sorghum biomass yields using fraction of absorbed photosynthetically active radiation derived from Sentinel-2 Satellite Imagery and Supervised Machine Learning Techniques. Agronomy 9(4):203. https://doi.org/10.3390/agronomy9040203

Hao X, Thomas B, Nelson V, Li X (2016). Agronomic values of anaerobically digested cattle manure and the separated solids for barley forage production. Soil Fertility \& Plant Nutrition 80:15721584. https://doi.org/10.2136/sssaj2016.05.0132

Hassan MU, Chattha MU, Mahmood A, Sahi ST (2018). Performance of sorghum cultivars for biomass quality and biomethane yield grown in semi-arid area of Pakistan. Environmental Science and Pollution Research 25:1280012807. https://doi.org/10.1007/s11356-018-1575-4

Ikanović J, Glamoclija DJ, Maletic R, Popović V, Sokolović D, Spasić M, Rakić S (2011). Path analysis of the productive traits in Sorghum species. Genetika 43(2):253-262. https://doi.org/10.2298/GENSR1102253I

Ikanović J, Živanović Lj, Popović V, Kolarić Lj, Dražić G, Janković S, Pavlović S (2018). Possibility of greater use of maize as a bioenergy. Journal of PKB Institute of Agroekonomik 24(1-2):49-59.

Jankovic S, Glamoclija DJ, Prodanovic S (2017). Energy crops - Technology for production and processing. Belgrade, ISBN 987-86-81689-35-6, pp 1-410. (In Serbian).

Kirubakarana V, Sivaramakrishnanb V, Nalinic R, Sekard T, Premalathae M, Subramaniane P (2009). A review on gasification of biomass. Renewable and Sustainable Energy Reviews 13:179-186. https://doi.org/10.1016/j.rser.2007.07.001

Lakic Z, Glamoclija DJ, Popovic V, Pavlovic S, Kondic D (2018). Fodder plants and cereals in the function of soil protection against degradation. Faculty of Agriculture. Banja Luka 269-275 (In Serbian).

Mahmood A, Ullah H, Ijaz M, Javaid M, Shahzad AN, Honermeier B (2013) Evaluation of sorghum hybrids for biomass and biogas production. Australian Journal for Crop Sciences 7(10):1456-1462. 
Mahmood A, Abrar H, Shahzad A N, Bernd H (2015). Biomass and biogas yielding potential of sorghum as affected by planting density, sowing time and cultivar. Pakistan Journal of Botany 47:2401-2408.

Makadi M, Tomocsik A, Orosz V (2012). Digestate: A new nutrient source - a review. In: Kumar S (Ed). Biogas. In Tech, pp 295-310. https://doi.org/10.5772/31355

Milanović T, Popović V, Vučković S, Rakaščan N, Popović S, Petković Z (2020). Analysis of soybean production and biogas yield to improve eco-marketing and circular economy. Economics of Agriculture, Belgrade, 67(1):141156. https://doi.org/10.5937/ekoPolj2001141M

Mekdad A, Rady M (2016). Productivity response to plant density in five Sorghum bicolor varieties in dry environments. Annals of Agricultural \& Crop Sciences 1(2):531-546.

Mortola N, Romaniuk R, Cosentino V, Eiza M, Carfagno P, Rizzo P, ... Brutti L (2019). Potential use of a poultry manure digestate as a biofertiliser: Evaluation of soil properties and Lactuca sativa growth. Pedosphere 29(1):60-69. https://doi.org/10.1016/S1002-0160(18)60057-8

Nabel MD, Schrey S, Poorter H, Koller R, Jablonowski N (2017). Effects of digestate fertilization on Sida hermaphrodita: Boosting biomass yields on marginal soils by increasing soil fertility. Biomass and Bioenergy 107:207-213. https://doi.org/10.1016/j.biombioe.2017.10.009

Nelson D, Sommers L (1996). Chapter 34 total carbon, organic carbon, and organic matter. In: Sparks DL, Page AL, Helmke PA, Loeppert RH, Soltanpour PN, Tabatabai MA, Johnston CT, Sumner ME (Eds). Methods of Soil Analysis: Part 3 Chemical Methods, 5.3. Soil Science Society of America, Inc., American Society of Agronomy, Inc. https://doi.org/10.2136/sssabookser5.3.c34

Nkoa R (2014). Agricultural benefits and environmental risks of soil fertilization with anaerobic digestates: a review. Agronomy for Sustainable Development 34:473-492. https://doi.org/10.1007/s13593-013-0196-Z

Pham CH, Triolo JM, Cu TTT, Pedersen L, Sommer SG (2013). Validation and recommendation of methods to measure biogas production potential of animal manure. Asian-Australasian Journal of Animal Science 26(6):864-873. https://doi.org/10.5713/ajas.2012.12623

Paterson AH, Bowers JE, Bruggmann R (2009). The Sorghum bicolorgenome and the diversification of grasses. Nature 457:551-556. https://doi.org/10.1038/nature07723

Popović V, Stevanović P, Vučković S, Ikanović J, Rajičić V, Bojović R, Jakšić S (2019). Influence of CAN fertilizer and seed inoculation with NS Nitragin on Glycine max plant on pseudogley soil type. Agriculturae Conspectus Scientificus 84(2):165-171. https://hrcak.srce.hr/221760

Popović V, Vučković S, Jovović Z, Ljubičić N, Kostić M, Rakaščan N, ... Ikanović J (2020a). Genotype by year interaction effects on soybean morpho-productive traits and biogas production. Genetika 52(3):1055-1073. https://doi.org/10.2298/GENSR1802635P

Popović V, Ljubičić N, Kostić M, Radulović M, Blagojević D, Ugrenovic V, ... Ivosevic B (2020b). Genotype x environment interaction for wheat yield traits suitable for selection in different seed priming conditions. Plants 9(12):1804. https://doi.org/10.3390/plants9121804

Prask H, Szlachta J, Fugol M, Kordas L, Lejman A, Tuznik F, Tuznik F (2018). Sustainability biogas production from ensiled plants consisting of the transformation of the digestate into a valuable organic-mineral granular fertilizer. Sustainability 10(3):585. https://doi.org/10.3390/su10030585

Przygocka-Cyna K, Grzebisz W (2018). Biogas digestate - benefits and risks for soil fertility and crop quality - an evaluation of grain maize response. Open Chemistry 16:258-271. https://doi.org/10.1515/chem-2018-0027

Przygocka-Cyna K, Grzebisz W (2020). The multifactorial effect of digestate on the availability of soil elements and grain yield and its mineral profile-the case of maize. Agronomy 10:275. https://doi.org/10.3390/agronomy10020275

Rajičić V, Popović V, Perišić V, Biberdžić M, Jovović Z, Gudžić N, ... Terzić D (2020b). Impact of nitrogen and phosphorus on grain yield in winter triticale grown on degraded vertisol. Agronomy 10(6):757. https://doi.org/10.3390/agronomy10060757.

Rakašćan N, Popović V, Dražić G, Ikanović J, Popović S, Popović B, Milanović T (2019). Circular economy in function of obtaining the biogas. XXIII International Eco-Conference ${ }^{\circledR}$, XIII Environmental Protection of Urban and Suburban Settlements, 25-27.09.2019. Novi Sad, pp 320-329.

Scarlat N, Fahl F, Dallemand J-F, Monforti F, Motola V (2018). A spatial analysis of biogas potential from manure in Europe. Renewable and Sustainable Energy Reviews 94:915-930. https://doi.org/10.1016/j.rser.2018.06.035

Simon T, Kunzová E, Friedlová M (2015). The effect of digestate, cattle slurry and mineral fertilization on the winter wheat yield and soil quality parameters. Plant Soil Environment 61:522-527. https://doi.org/10.17221/530/2015-PSE 
Spalevic V, Barovic G, Vujacic D, Curovic M, Behzadfar M, Djurovic N, ... Billi P (2020). The Impact of land use changes on soil erosion in the river basin of Miocki Potok, Montenegro. Water 12(11):2973. https://doi.org/10.3390/w12112973

Stürmer B, Pfundtner E., Kirchmeyr F, Uschnig S (2020). Legal requirements for digestate as fertilizer in Austria and the European Union compared to actual technical parameters. Journal of Environmental Management 253:109756. https://doi.org/10.1016/j.jenvman.2019.109756

Tambone F, Scaglia B, D’Imporzano G, Schievano A, Orzi V, Salati S, Adani F (2010). Assessing amendment and fertilizing properties of digestates from anaerobic digestion through a comparative study with digestated sludge and compost. Chemosphere 81(5):577-583. https://doi.org/10.1016/j.chemosphere.2010.08.034

Tapparo DC, Do Amaral AC, Radis RL, Kunz A (2019). Co-digestion of animal manure and carcasses to increase biogas generation. In: Treichel H, Fongaro G (Eds). Improving biogas production: Technological Challenges, Alternative Sources, Future Developments. Improving Biogas Production. Biofuel and Biorefinery Technologies 9. Springer Cham, pp 99-116. https://doi.org/10.1007/978-3-030-10516-7_5

Verdi L, Kuikman PL, Orlandini S, Mancini M, Napoli M, Dalla Marta A (2019). Does the use of digestate to replace mineral fertilizers have less emissions of $\mathrm{N}_{2} \mathrm{O}$ and $\mathrm{NH}_{3}$ ? Agricultural and Forest Meteorology 269:112-118. https://doi.org/10.1016/j.agrformet.2019.02.004

Wannasek L, Ortner M, Amon B, Amon T (2017). Sorghum, a sustainable feedstock for biogas production? Impact of climate, variety and harvesting time on maturity and biomass yield. Biomass and Bioenergy 106:137-145. https://doi.org/10.1016/j.biombioe.2017.08.031

Zegada-Lizarazu W, Monty A (2011). Energy crops in rotation: A review. Biomass and Bioenergy 35(1):12-25. https://doi.org/10.1016/j.biombioe.2010.08.001
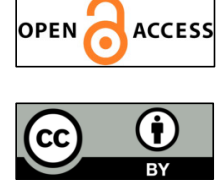

The journal offers free, immediate, and unrestricted access to peer-reviewed research and scholarly work. Users are allowed to read, download, copy, distribute, print, search, or link to the full texts of the articles, or use them for any other lawful purpose, without asking prior permission from the publisher or the author.

License - Articles published in Notulae Botanicae Horti Agrobotanici Cluj-Napoca are Open-Access, distributed under the terms and conditions of the Creative Commons Attribution (CC BY 4.0) License.

(c) Articles by the authors; UASVM, Cluj-Napoca, Romania. The journal allows the author(s) to hold the copyright/to retain publishing rights without restriction. 